\title{
The influence of menopause on urinary incontinence in the women of the community: a cross-sectional study from North India
}

\author{
Samreen Khan ${ }^{1 *}$, M. Athar Ansari ${ }^{1}$, Shaista M. Vasenwala ${ }^{2}$, Zehra Mohsin ${ }^{3}$
}

${ }^{1}$ Department of Community Medicine, ${ }^{2}$ Department of Pathology, ${ }^{3}$ Department of Obstetrics \& Gynaecology, Jawahar Lal Nehru Medical College, A.M.U., Aligarh, Uttar Pradesh, India

Received: 16 December 2016

Accepted: 31 January 2017

\author{
*Correspondence: \\ Dr. Samreen Khan, \\ E-mail: drsamreen2k4@gmail.com
}

Copyright: () the author(s), publisher and licensee Medip Academy. This is an open-access article distributed under the terms of the Creative Commons Attribution Non-Commercial License, which permits unrestricted non-commercial use, distribution, and reproduction in any medium, provided the original work is properly cited.

\begin{abstract}
Background: Urinary incontinence is defined as the complaint of any involuntary loss of urine that is a social or hygienic problem. Worldwide, over 200 million people are living with urinary incontinence and as the life expectancy of women is increasing, more number of women are bound to suffer from it. The aim of the present study is to find out the effect of menopause on the occurrence of Urinary Incontinence in women and to find out risk factors in post-menopausal women associated with Urinary Incontinence.

Methods: It was a community based cross-sectional study involving post-menopausal women living in the urban and rural areas registered under Community Medicine, J.N. Medical College, Aligarh, India. A total of 530 women were taken for this study. Descriptive statistics as well as simple proportion were calculated with SPSS 20.0. Tests of significance and Binary Logistic regression analysis were used for analysis.

Results: Significant differences were found in the association of Urinary Incontinence with increasing age groups and consequent years spent in menopause, rural area of residence, illiteracy, lower socio-economic class, inadequate housing standards, obesity, smoking, parity, history of hysterectomy, and co-morbidities such as Urinary Tract Infection and Pelvic organ prolapse.

Conclusions: From a public health perspective, there is considerable opportunity to improve women's quality of life by increasing health education about urinary incontinence and its treatment by taking steps for life style modifications.
\end{abstract}

Keywords: Menopause, Post-menopausal women, Risk factors, Rural, Urban, Urinary incontinence

\section{INTRODUCTION}

Urinary incontinence is a common problem amongst adults living in the community. ${ }^{1}$ Control of micturition is a complex physiological and anatomical process which often fails in women. According to the International Continence Society (ICS), urinary incontinence (UI) is defined as: the complaint of any involuntary loss of urine that is a social or hygienic problem. ${ }^{2}$ Worldwide, over 200 million people are living with urinary incontinence. ${ }^{3}$ It is three times more common in women than men. ${ }^{4}$
Urinary incontinence is a troublesome and probably underreported disorder in women. ${ }^{5}$ Estimated $19 \%$ of women under the age of 45 experience UI and $29 \%$ of women over the age of 80 also experience this condition. ${ }^{6}$ The prevalence of UI in community-dwelling women ranges from $10 \%$ to $40 \%$. In general, the overall prevalence rate of UI increases with age. ${ }^{7}$ Numerous epidemiologic studies show that the incidence of UI increases with age, with the range of prevalence estimates among community dwelling patients varying enormously from $2 \%$ to $58 \% .^{8}$ Elderly women are the most affected, 
with a mean prevalence of $34 \% .{ }^{9}$ Women suffering from urinary incontinence constitute about $70-80 \%$ of female patients reporting to a physician due to urinary system diseases. ${ }^{10}$ It is estimated that $25-45 \%$ of women of different ages have involuntary urine loss and 9-39\% of women over 60 years report daily urinary leakage. ${ }^{11,12}$ The prevalence of urinary incontinence peaks at 50-54 years of age and may diminish quality of life and disrupt daily routines. ${ }^{13}$ Recently, as the average life expectancy of women has increased and an increasing number of women maintain various social roles after menopause, urinary incontinence (UI) has become an important medical and social issue. ${ }^{14}$

\section{Etio-pathology}

Urinary continence is due to the fact that bladder pressure remains lower than urethral closure pressure, and incontinence may result from bladder or urethral impairment; when closure pressure is lower than bladder pressure, leakage occurs. ${ }^{15}$ The low estrogen production during and after menopause produces symptoms from the autonomic nervous system such as flushing and perspiration and psychiatric symptoms such as depression. Furthermore, the mucous membranes of the genitourinary tract undergo atrophy resulting in vaginitis, dyspareunia and cyato-urethritis. ${ }^{16}$

\section{Types of UI}

Three types of incontinence are generally known: stress urinary incontinence (SUI); urge urinary incontinence (UUI), and mixed urinary incontinence (MUI), which associates the first two. ${ }^{15}$ Stress is most common occurring in pure or mixed forms, in $80 \%$ women with incontinence defined as the complaint of involuntary leakage on effort or exertion, or on sneezing or coughing. ${ }^{11,14,16}$. In a majority of cases urinary incontinence in women is stress-related before the age of 50 and mixed after the age of $50 .{ }^{17}$ Despite its high prevalence, little is known about associated risk factors, and the etiology of urinary incontinence is poorly written. Various factors associated with lifestyle are thought to precipitate lower urinary tract symptoms and urinary incontinence, for example, ageing, pregnancy, vaginal delivery, obesity physical forces (exercise, work), smoking, caffeine and fluid intake, constipation, posture. ${ }^{15,18,19}$ Urinary incontinence upsets persons' freedom and ability to function in everyday life. It has therefore become a public health problem, with a high economic and human impact. ${ }^{20}$ Although interest is growing in the investigation, treatment, and management of incontinence, its prevalence in the general population has so far been based on estimates made in selected groups of people of different ages. ${ }^{21}$ Therefore, the following study was carried out with the two objectives; one is to find out the effect of menopause on the occurrence of Urinary Incontinence in women and second is to find out risk factors in post-menopausal women associated with Urinary Incontinence.

\section{METHODS}

It was a community based cross sectional study. All the households registered under Urban Health and Training Centre (UHTC) and Rural Health and Training Centre (RHTC), Department of Community Medicine, J. N. Medical College, Aligarh were taken under the sampling frame. The study period was one year i.e. from June, 2012 to May, 2013. All postmenopausal women who are residents of the study areas of UHTC and RHTC were included. Women who did not give consent, those who had not attained menopause, those who were receiving hormone replacement therapy (HRT). Systematic random sampling and proportionate to population size method (PPS). Sample Size estimated after doing a thorough Review of Literature where it was found that the prevalence ranges from $0-60 \% .^{6-10,20-24}$ Taking a mean prevalence as $30 \%$, relative error of $20 \%$ of p. Using Formula: $\mathrm{N}=\mathrm{z}^{2} \mathrm{pq} / \mathrm{L}^{2}$, we got the sample size as 233 . Taking design effect of 2 and applying non-response rate of $5 \%$, we finally took a sample size of 530 postmenopausal women. They were chosen by systematic random sampling with population proportion to sample (PPS) method taking equal samples from rural and urban areas.

\section{Study Tool}

Four-item incontinence questionnaire was used to assess the type of urinary incontinence was defined by an affirmative response to one of four questions:

- During the past 12 months have you experienced urine loss when coughing, sneezing, laughing, or doing some other activity?

- During the past 12 months have you ever had to urinate and then wet yourself before getting to the toilet?

- Do you have to urinate more than eight times in the daytime?

- Do you have to urinate more than three times at night?

Mixed incontinence was defined as an affirmative answer to the first question and to the second, third, or forth question; stress incontinence as "yes" to only the first question; urge incontinence as "yes" to the second, third, or forth question ("no" to the first question). No incontinence was defined as "no" to all questions. The severity of stress incontinence was assessed by the frequency of urine loss during performance of ordinary to provocative activities: sneezing and coughing (mild); jumping, running, stair climbing, and carrying heavy things (moderate); dish or hand washing, walking, and daily routines (severe). These questions have been proven to have high specificity and sensitivity for stress and urge incontinence. ${ }^{21}$ Severity of UI was assessed by Urinary incontinence severity indicator given by Sandvik et al. ${ }^{22}$

\section{Statistical analysis}


Data was analyzed using Statistical package for social sciences (SPSS) version 23.0 (IBM, Chicago, USA). Descriptive statistics as well as simple proportion were calculated for the data. Chi-square test and logistic regression with $95 \%$ confidence interval to find the most important variable affecting diabetes related foot problems were used. The value of $\mathrm{p}<0.05$ was considered as significant for this study.

\section{RESULTS}

As shown by the Figure 1, the present study shows presence of UI varying over different age groups in the urban and rural areas. Figure 2 shows a bar graph depicting the type of UI stratified according to age groups. Maximum patients were of Mild UI, followed by moderate and severe age groups in all age groups. As the age increases, the number of patients increase except for the age group 51-60 years which is due to the reason that the maximum number of study participants were from this age group. Figure 3 shows the complaints of the patients. More number of patients were from urban areas and they complained of increased frequency of micturition, pain or burning sensation during micturition, dribbling of urine and urgency of urination in decreasing order.

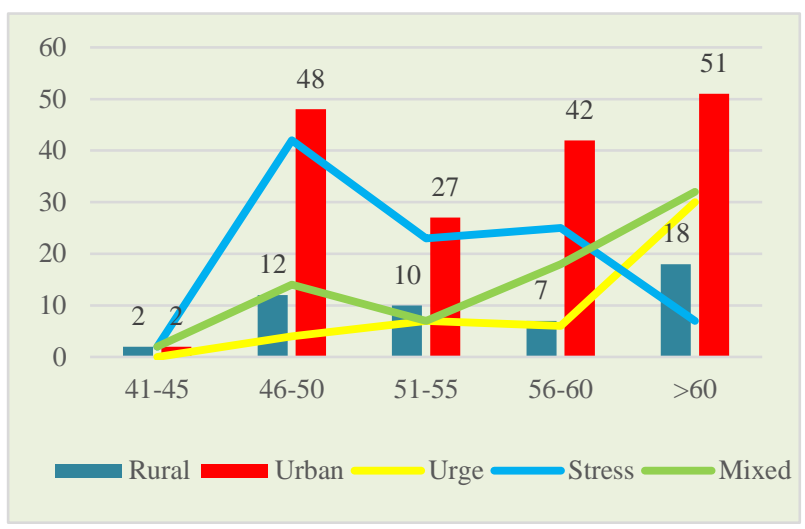

Figure 1: Type of urinary incontinence (UI) among the study participants according to area of residence and age ( $X$ axis: Age groups, Bar graph showing Area of residence and line diagram showing type of UI, Y axis: Number of study participants).

Table 1: Association of type of urinary incontinence (UI) with age and number of years spent in menopause.

\begin{tabular}{|c|c|c|c|c|c|c|}
\hline & Urge UI & Stress UI & Mixed UI & UI Absent & $\begin{array}{l}\text { Chi square } \\
\text { value }\end{array}$ & p value \\
\hline \multicolumn{7}{|l|}{ Age groups } \\
\hline $41-45$ years & $0(0.0)$ & $2(16.7)$ & $2(16.7)$ & $8(66.7)$ & \multirow{5}{*}{85.121} & \multirow{5}{*}{0.000} \\
\hline $46-50$ years & $4(3.5)$ & $42(36.8)$ & $14(12.3)$ & $54(47.4)$ & & \\
\hline $51-55$ years & $7(7.1)$ & $23(23.5)$ & $7(7.1)$ & $61(62.2)$ & & \\
\hline $56-60$ years & $6(3.8)$ & $25(15.9)$ & $18(11.5)$ & $108(68.8)$ & & \\
\hline$>60$ years & $30(20.1)$ & $7(4.7)$ & $32(21.5)$ & $80(53.7)$ & & \\
\hline \multicolumn{7}{|c|}{ Years spent in menopause } \\
\hline $1-5$ & $11(6.7 \%)$ & $56(34.1)$ & $16(9.8)$ & $81(49.4)$ & \multirow{4}{*}{82.424} & \multirow{4}{*}{0.000} \\
\hline $6-10$ & $3(2.3)$ & $23(17.6)$ & $11(8.4)$ & $94(71.8)$ & & \\
\hline $11-15$ & $4(4.6)$ & $13(14.9)$ & $18(20.7)$ & $52(59.8)$ & & \\
\hline$>15$ & $29(19.7)$ & $7(4.8)$ & $28(19.0)$ & $83(56.5)$ & & \\
\hline
\end{tabular}

Uni-variate analysis of variation: post hoc Bonferroni test between number of years spent in menopause and type of UI using SPSS 23.0

\begin{tabular}{|l|l|l|l|l|l|l|}
\hline $\begin{array}{l}\text { Years in } \\
\text { Menopause (I) }\end{array}$ & $\begin{array}{l}\text { Years in } \\
\text { menopause }(\mathbf{J})\end{array}$ & $\begin{array}{l}\text { Mean Difference } \\
\text { (I-J) }\end{array}$ & $\begin{array}{l}\text { Standard } \\
\text { Error }\end{array}$ & p value & \multicolumn{2}{|l|}{ 95\% Confidence Interval (CI) } \\
\hline \multirow{3}{*}{$1-5$} & $6-10$ & $-21.7251^{*}$ & 5.53030 & 0.001 & -36.3710 & -7.0792 \\
\hline & $11-15$ & -10.1989 & 6.25966 & 0.623 & -26.7763 & 6.3785 \\
\hline \multirow{3}{*}{$6-10$} & $>15$ & -6.8229 & 5.36037 & 1.000 & -21.0187 & 7.3730 \\
\hline \multirow{3}{*}{$11-15$} & $1-5$ & $21.7251^{*}$ & 5.53030 & 0.001 & 7.0792 & 36.3710 \\
\hline & $11-15$ & 11.5262 & 6.52722 & 0.468 & -5.7598 & 28.8122 \\
\hline \multirow{3}{*}{$>15$} & $>15$ & 14.9022 & 5.67052 & 0.053 & -0.1150 & 29.9194 \\
& $1-5$ & 10.1989 & 6.25966 & 0.623 & -6.3785 & 26.7763 \\
\hline & $6-10$ & -11.5262 & 6.52722 & 0.468 & -28.8122 & 5.7598 \\
\hline & $>15$ & 3.3760 & 6.38388 & 1.000 & -13.5304 & 20.2824 \\
\hline
\end{tabular}

Based on observed means. The error term is Mean Square (Error) $=2227.359$. $*$ The mean difference is significant at the 0.05 level. 
Table 2a: Socio-demographic profile related to the presence of urinary incontinence (UI) in the study participants.

\begin{tabular}{|c|c|c|c|c|c|c|}
\hline Variable & $\begin{array}{l}\text { Absent } \\
* \mathbf{N}(\%)\end{array}$ & $\begin{array}{l}\text { Present } \\
* \mathbf{N}(\%)\end{array}$ & $\begin{array}{l}\text { Chi square } \\
\text { value }\end{array}$ & p value & Odd's ratio & $\begin{array}{l}\text { 95\% Confidence Interval } \\
\text { (Upper limit-Lower Limit) }\end{array}$ \\
\hline \multicolumn{7}{|l|}{ Residence } \\
\hline Rural & $216(81.5)$ & $49(18.5)$ & \multirow{2}{*}{1.139} & \multirow{2}{*}{0.000} & 0.127 & $0.085-0.189$ \\
\hline Urban & $95(35.8)$ & $170(64.2)$ & & & 1 (ref) & \\
\hline \multicolumn{7}{|l|}{ Religion } \\
\hline Hindu & $172(67.5)$ & $83(32.5)$ & \multirow{4}{*}{15.739} & \multirow{4}{*}{0.001} & 0.483 & $0.067-3.468$ \\
\hline Muslim & $133(50.8)$ & $129(49.2)$ & & & 0.970 & 0.1335-.989 \\
\hline Christian & $4(44.4)$ & $5(55.6)$ & & & 1.250 & $0.118-3.240$ \\
\hline Others & $2(50.0)$ & $2(50.0)$ & & & 1 (ref) & \\
\hline \multicolumn{7}{|l|}{ Marital status } \\
\hline Married & $241(71.5)$ & $96(28.5)$ & \multirow{3}{*}{66.014} & \multirow{3}{*}{0.000} & 0.247 & $0.168-0.363$ \\
\hline Single & $3(16.7)$ & $15(83.3)$ & & & 3.102 & $0.865-11.11$ \\
\hline Widowed & $67(38.3)$ & $108(61.7)$ & & & 1 (ref) & \\
\hline \multicolumn{7}{|l|}{ + Education status } \\
\hline $\begin{array}{l}\text { Illiterate, Non-formal } \\
\text { education }\end{array}$ & $268(62.8)$ & $159(37.2)$ & \multirow{4}{*}{25.286} & \multirow{4}{*}{0.000} & 0.334 & $0.144-0.773$ \\
\hline Primary & $12(27.9)$ & $31(72.1)$ & & & 1.452 & $0.506-4.169$ \\
\hline High school & $22(62.9)$ & $13(37.1)$ & & & 0.332 & $0.114-0.965$ \\
\hline Intermediate and above & $9(36.0)$ & $16(64.0)$ & & & 1 (ref) & \\
\hline \multicolumn{7}{|l|}{ \$Occupation } \\
\hline $\begin{array}{l}\text { Unemployed/retired/ho } \\
\text { memaker }\end{array}$ & $263(61.2)$ & $167(38.8)$ & 6.439 & 0.169 & 1.270 & $0.114-14.115$ \\
\hline Unskilled/ Semi-skilled & $34(48.6)$ & $36(51.4)$ & & & 2.118 & $0.184-24.437$ \\
\hline Skilled & $2(50.0)$ & $2(50.0)$ & & & 2.000 & $0.090-44.350$ \\
\hline $\begin{array}{l}\text { Clerical/ /Shopkeeper } \\
\text { / Farmer }\end{array}$ & $10(43.5)$ & $13(56.5)$ & & & 2.600 & $0.205-32.904$ \\
\hline Professional & $2(66.7)$ & $1(33.3)$ & & & 1 (ref) & \\
\hline \multicolumn{7}{|l|}{ Source of Income } \\
\hline Self & $40(45.5)$ & $48(54.5)$ & 38.356 & 0.000 & 0.400 & $0.120-1.337$ \\
\hline Spouse & $99(79.8)$ & $25(20.2)$ & & & 0.084 & $0.025-0.283$ \\
\hline Children & $152(56.3)$ & $118(43.2)$ & & & 0.259 & $0.081-0.823$ \\
\hline Old age pension Schemes & $16(50.0)$ & $16(50.0)$ & & & 0.333 & $0.088-1.256$ \\
\hline Others & $4(25.0)$ & $12(75.0)$ & & & 1 (ref) & \\
\hline
\end{tabular}

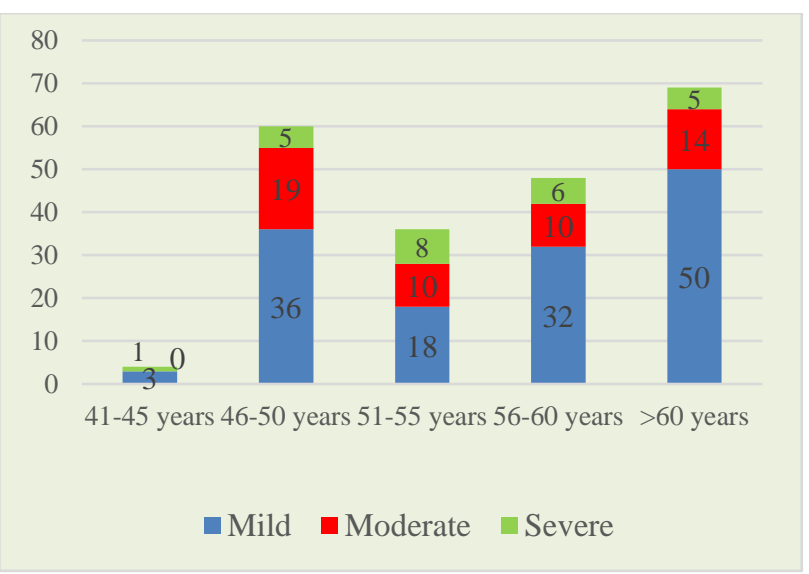

Figure 2: Severity and distribution of urinary Incontinence over increasing age groups in postmenopausal women in the present study ( $X$ axis: Age groups (in years), $\mathrm{Y}$ axis: Number of patients $(\mathrm{N})$.

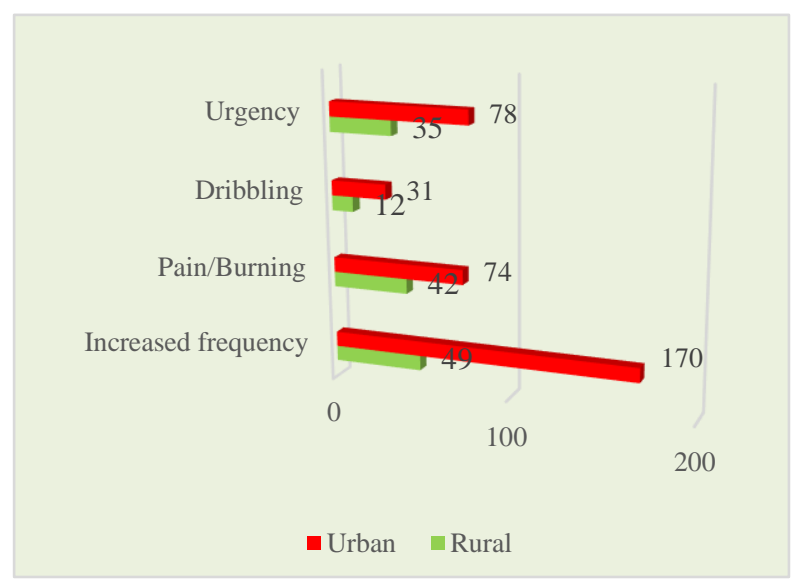

Figure 3: Bar graph depicting urinary complaints of the study participants according to area of residence in the present study ( $X$ axis: Number of patients $(N)$, Y axis: Complaints). 
Table 1 documents the significant difference found between years spent in menopause and type of UI diagnosed on the basis of history from the patient. It is shown that the maximum number of patient are of Stress UI. As the age increases, the number of cases of Mixed UI increases. On application of Univariate analysis of variation, post hoc Bonferroni test, it is seen that a signification association is seen between. Table 2 (a and b) shows the Socio-demographic profile related to the presence of Urinary Incontinence in the study participants. $49(18.5 \%)$ from the rural areas and 170 (64.2\%) from the urban areas were diagnosed with the condition and the difference was found to be significant with odds of 0.127 (CI 0.085-0.189) of rural against urban area of residence. $129(49.2 \%)$ of the Muslims had UI. Majority of the patients having UI were widowed, illiterate and unemployed/ retired or homemakers with their children as the main source of income. Most of the cases of UI belonged to Modified BG Prasad's Class II having a medium Standard of Life Index. Regarding the residential conditions, $136(41.7 \%)$ of the study participants living in congested localities, $122(39.0 \%)$ of those having overcrowded households and 59 (31.2\%) having inadequate ventilation in their households had UI.

Table 2b: Socio-demographic profile related to the presence of urinary incontinence (UI) in the study participants.

\begin{tabular}{|c|c|c|c|c|c|c|}
\hline Variables & $\begin{array}{l}\text { Absent } \\
* \mathbf{N}(\%)\end{array}$ & $\begin{array}{l}\text { Present } \\
* \mathbf{N}(\%)\end{array}$ & $\begin{array}{l}\text { Chi square } \\
\text { value }\end{array}$ & p value & Odd's ratio & $\begin{array}{l}\text { 95\% Confidence Interval } \\
\text { (Upper limit-Lower Limit) }\end{array}$ \\
\hline \multicolumn{7}{|c|}{ Standard of living index } \\
\hline Low & $138(72.6)$ & $52(27.4)$ & \multirow{3}{*}{32.236} & \multirow{3}{*}{0.082} & 0.635 & $0.380-1.060$ \\
\hline Medium & $109(45.8)$ & $129(54.2)$ & & & 1.993 & $1.239-3.207$ \\
\hline High & $64(62.7)$ & $38(37.3)$ & & & 1 (ref) & \\
\hline \multicolumn{7}{|c|}{$\uparrow$ Socio-economic classification } \\
\hline I & $139(71.6)$ & $55(28.4)$ & \multirow{5}{*}{66.697} & \multirow{5}{*}{0.000} & 0.778 & $0.454-1.334$ \\
\hline II & $62(34.8)$ & $116(65.2)$ & & & 3.680 & $2.151-6.294$ \\
\hline III & $30(83.3)$ & $6(16.7)$ & & & 0.393 & $0.148-1.049$ \\
\hline IV & $21(63.6)$ & $12(36.4)$ & & & 1.124 & $0.488-2.589$ \\
\hline V & $59(66.3)$ & $30(33.7)$ & & & 1 (ref) & \\
\hline \multicolumn{7}{|c|}{ Locality of home } \\
\hline Congested & $190(58.3)$ & $136(41.7)$ & 0.055 & 0.443 & 0.958 & $0.671-1.368$ \\
\hline Not Congested & $121(59.3)$ & $83(40.7)$ & & & 1 (ref) & \\
\hline \multicolumn{7}{|l|}{ Over-crowding } \\
\hline Present & $191(61.0)$ & $122(39.0)$ & 1.731 & 0.110 & 1.266 & $0.891-1.798$ \\
\hline Absent & $120(55.0)$ & $97(44.7)$ & & & 1 (ref) & \\
\hline \multicolumn{7}{|l|}{ Ventilation } \\
\hline Present & $130(68.8)$ & $59(31.2)$ & 12.368 & 0.000 & 0.513 & $0.353-0.746$ \\
\hline Absent & $181(53.1)$ & $160(46.9)$ & & & 1 (ref) & \\
\hline \multicolumn{7}{|l|}{ || Obesity } \\
\hline Present & $213(62.5)$ & $128(37.5)$ & 5.647 & 0.011 & 0.647 & $0.452-0.927$ \\
\hline Absent & $98(51.9)$ & $91(48.1)$ & & & 1 (ref) & \\
\hline \multicolumn{7}{|l|}{ Smoking } \\
\hline Present & $52(46.0)$ & $61(54.0)$ & 9.496 & 0.002 & 1.923 & $1.264-2.925$ \\
\hline Absent & $259(62.1)$ & $158(37.9)$ & & & 1 (ref) & \\
\hline \multicolumn{7}{|l|}{ Pack-years } \\
\hline$<10$ years & $4(50.0)$ & $4(50.0)$ & 11.191 & 0.011 & 1.639 & $0.404-6.647$ \\
\hline $10-20$ years & $28(41.2)$ & $40(58.8)$ & & & 2.342 & $1.390-3.946$ \\
\hline$>20$ years & $20(54.1)$ & $17(45.9)$ & & & 1.393 & $0.709-2.740$ \\
\hline Non-smokers & $259(62.1)$ & $158(37.9)$ & & & 1 (ref) & \\
\hline \multicolumn{7}{|c|}{ Tobacco chewing } \\
\hline Present & $59(54.6)$ & $49(45.4)$ & 0.971 & 0.198 & 1.231 & $0.804-1.885$ \\
\hline Absent & $252(59.7)$ & $170(40.3)$ & & & 1 (ref) & \\
\hline
\end{tabular}

$†$ Modified B. G. Prasad Classification27; *N= Number of study participants; || Body Mass Index= Weight in Kilograms/ (Height in centimeters). 
After calculating BMI and assessing with the help of WHO Classification for Asians, Obesity, 128 (37.5\%) of the patients having $\mathrm{BMI}>23$ were found to be suffering from UI. This was found to be significant with an odds of 0.647 as compared to the smokers, amongst whom 61 $(54.0 \%)$ were found to be suffering from UI with an odds of 1.923 (CI 1.264-2.925) for the presence of UI. When the number of pack years were calculated and compared, the value of $p$ was found to be significant. Compared with the non-smokers, the odds for smokers with packyears of less than 10 years, 10-20 years and more than 20 years were 1.639 (95\% CI 0.404-6.647), 2.342 (95\% CI $1.390-3.946)$ and $1.393 \quad(95 \%$ CI $0.709-2.740)$ respectively. Among those women who had the habit of tobacco chewing, 49 (45.4\%) had UI. This was not found to be significant.

As shown by Table 3, the increasing number of years spent in menopause had a significant association with the presence of UI in the study population. For 1-5, 5-10, 1115 and $>15$ years spent in menopause by a woman, the odd's for the presence of UI was found to be $1.329(95 \%$ CI $0.850-2.078), 0.510$ (95\% CI 0.309-0.842) and 0.873 (95\% CI $0.509-1.496)$ respectively. Increasing parity has always been found to be involved in the etiology of UI. In the present study, however significant difference was found in association was found between parity and UI, the odd's were 1.983 (95\% CI 1.092-3.601) and 2.00 (95\% CI 1.364-2.931) for parity <3 and 3-5 compared to parity more than 5 respectively. Nearly all study subjects had vaginal delivery out of whom 213 subjects $(41 \%)$ had UI. The odds were 0.463 (95\% CI $0.129-1.659)$. UI was present in $47(54.0 \%)$ of the total subjects who were hypertensive, $17(25.9 \%)$ of those who had Diabetes Mellitus, $77(92.8 \%)$ who had urinary tract infection and $51(50 \%)$ of all those who had the added morbidity of Pelvic Organ Prolapse. Out of these four co-morbidities, significant value of $\mathrm{p}$ was found with all except Diabetes Mellitus.

Among the significant ones, on applying Univariate logistic regression, the odd's ratio for the presence of UI was $1.851(95 \%$ CI 1.165-2.941) for Hypertension, $27.565(95 \%$ CI $11.731-64.767)$ for Urinary Tract Infection and 1.548 (95\% CI 1.003-2.388) for the simultaneous presence of Pelvic Organ Prolapse in the women.

Table 3: Association of urinary incontinence (UI) with patient specific history and examination findings.

\begin{tabular}{|c|c|c|c|c|c|c|}
\hline Variable & $\begin{array}{l}\text { Absent } \\
\mathbf{N}(\%)\end{array}$ & $\begin{array}{l}\text { Present } \\
\text { N }(\%)\end{array}$ & $\begin{array}{l}\text { Chi square } \\
\text { value }\end{array}$ & p value & Odd's ratio & $\begin{array}{l}\text { 95\% Confidence Interval } \\
\text { (Upper limit-Lower Limit) }\end{array}$ \\
\hline \multicolumn{7}{|c|}{ Years spent in menopause } \\
\hline $1-5$ years & $81(49.4)$ & $83(50.6)$ & 15.405 & 0.002 & 1.329 & $0.850-2.078$ \\
\hline $6-10$ years & $94(71.8)$ & $37(28.2)$ & & & 0.510 & $0.309-0.842$ \\
\hline $11-15$ years & $52(59.8)$ & $35(40.2)$ & & & 0.873 & $0.509-1.496$ \\
\hline$>15$ years & $83(56.5)$ & $64(43.5)$ & & & 1 (ref) & \\
\hline \multicolumn{7}{|l|}{ Parity } \\
\hline$<3$ children & $25(49.0)$ & $26(51.0)$ & 14.846 & 0.001 & 1.983 & $1.092-3.601$ \\
\hline 3-5 children & $82(48.8)$ & $86(51.2)$ & & & 2.000 & $1.364-2.931$ \\
\hline$>5$ children & $204(65.6)$ & $107(34.4)$ & & & 1 (ref) & \\
\hline \multicolumn{7}{|c|}{ Type of delivery } \\
\hline All vaginal & $307(59.0)$ & $213(41.0)$ & 1.467 & 0.226 & 0.463 & $0.129-1.659$ \\
\hline Caesarean & $4(40.0)$ & $6(60.0)$ & & & 1 (ref) & \\
\hline \multicolumn{7}{|c|}{ Hysterectomy } \\
\hline Present & $4(5.5 \%)$ & $69(94.5 \%)$ & 98.821 & 0.000 & 0.028 & $0.010-0.079$ \\
\hline Absent & $307(67.2 \%)$ & $150(32.8 \%)$ & & & 1 (ref) & \\
\hline \multicolumn{7}{|l|}{ Hypertension } \\
\hline Present & $40(46.0)$ & $47(54.0)$ & 6.926 & 0.006 & 1.851 & $1.165-2.941$ \\
\hline Absent & $271(61.2)$ & $172(38.8)$ & & & 1 (ref) & \\
\hline \multicolumn{7}{|c|}{ Diabetes Mellitus } \\
\hline Present & $20(54.1)$ & $17(45.9)$ & 0.351 & 0.335 & 1.225 & $0.626-2.395$ \\
\hline Absent & $291(59.0)$ & $202(41.0)$ & & & 1 (ref) & \\
\hline \multicolumn{7}{|c|}{ Urinary tract infection } \\
\hline Present & $6(7.2)$ & $77(92.8)$ & 1.074 & 0.000 & 27.565 & $11.731-64.767$ \\
\hline Absent & $305(68.2)$ & $142(31.8)$ & & & 1 (ref) & \\
\hline \multicolumn{7}{|c|}{ Pelvic organ prolapse } \\
\hline Present & $51(50.0)$ & $51(50.0)$ & 3.924 & 0.031 & 1.548 & $1.003-2.388$ \\
\hline Absent & $260(60.7)$ & $168(39.3)$ & & & 1 (ref) & \\
\hline
\end{tabular}




\section{DISCUSSION}

The present study shows a greater burden of UI in urban areas, increasing with age, although not linearly in both the areas. Many studies have supported this finding. ${ }^{23-25}$ Maximum number of patients of mild Incontinence shows that a major chunk from the burden of disease goes unreported. In a urodynamic clinic, patients attend with two main types of incontinence, stress urinary incontinence and incontinence caused by detrusor instability; these affect $90 \%$ of the population at some time in their lives. ${ }^{11}$ As seen in the present study, it has been suggested that vaginal delivery is the main contributing factor, possibly because of damage to important muscle tissue or nerves. ${ }^{19}$ Although a study documents that incontinence was not related to the type of delivery, and post-natal exercises for the pelvic floor were not beneficial. ${ }^{1}$ Our study shows increased risk of UI is increased in postmenopausal women who had undergone hysterectomy compared with women with uteri as shown by other research studies. ${ }^{18,19} \mathrm{We}$ found a risk of nearly 27 times for UI in the co-presence of UTI (95\% CI 11.731-64.767). Jackson et al reported that a history of urinary tract infection (UTI) and measures of general health were associated with UI and women with diabetes reported disproportionately more severe incontinence, BMI confounds the relationship between diabetes and incontinence among healthy postmenopausal women. ${ }^{3}$ Although we found a significant relationship in our study with obesity, but the relationship with Diabetes Mellitus was not found to be significant. Similar results were quoted by a multivariate analyses by Brown et al. ${ }^{20}$

Although not life-threatening, urinary incontinence (UI) is a major clinical problem that has a profound effect on quality of life and activities of daily living. ${ }^{5-7}$ Stress urinary incontinence and pelvic organ prolapse may coexist. ${ }^{10,24-25}$ Present study showed a 1.5 odds (95\% CI 1.003-2.388) of urinary incontinence in the presence of pelvic organ prolapse.

\section{CONCLUSION}

Although urinary incontinence is a common symptom, it is often not reported to doctors, which leads to under treatment. From a public health perspective, there is considerable opportunity to improve women's quality of life by increasing health education about urinary incontinence and its treatment. ${ }^{2}$ Stress and urge incontinence are common in postmenopausal women and have different risk factors, suggesting that approaches to risk-factor modification and prevention also might differ and should be specific to types of incontinence. ${ }^{20}$ Estimates may not accurately reflect the full scope of urinary incontinence as an embarrassment, and perceived stigmatization may cause women to be reluctant to communicate their concerns to physicians. The substantial psychosocial consequences of urinary incontinence stress the need for more public health and medical attention.

\section{ACKNOWLEDGEMENT}

Author is grateful to the Department of Community Medicine, Pathology and Obstetrics \& Gynaecology, J. N. Medical College, Aligarh for their contribution to the study.

\section{Funding: No funding sources}

Conflict of interest: None declared

Ethical approval: The study was approved by the Institutional Ethics Committee

\section{REFERENCES}

1. Jolleys JV. Reported prevalence of urinary incontinence in women in a general practice. $\mathrm{Br}$ Med J (Clin Res Ed). 1988;296:1300.

2. Hsieh CH, Su TH, Chang ST, Lin SH, Lee MC, Lee MY. Prevalence of and attitude toward urinary incontinence in postmenopausal women. International J Gynecol Obstet. 2008;100(2):171-4.

3. Jackson SL, Scholes D, Boyko EJ, Abraham L, Fihn SD. Urinary incontinence and diabetes in postmenopausal women. Diab Care. 2005;28(7):1730-8.

4. Jameel S, Mahmud SN. Frequency of different risk factors associated with Recurrent Urinary Tract Infection among Postmenopausal Women. J Ayub Med Coll Abbottabad. 2016;28(2):353-6.

5. Wyman J. The psychiatric and emotional impact of female pelvic floor dysfunction. Curr Opin Obstet Gynecol. 1994;6:336-9.

6. Hollywood B, O'Dowd T. Female urinary incontinence: another chronic illness. Br J Gen Pract. 1998;48:1727-8.

7. Grimby A, Milson I, Molander U et al. The influence of urinary incontinence on the quality of life of elderly women. Age Ageing. 1993;22:82-9.

8. Lam G, Foldspang A, Elving LB, Mommsem S. Social context, social abstention, and problem recognition correlated with adult female urinary incontinence. Dan Med Bull. 1992;39:565-70.

9. Bogner HR, Gallo JJ, Sammel MD, et al. Urinary incontinence and psychological distress in community-dwelling older adults. J Am Geriatr Soc. 2002;50:489-95.

10. Bai SW, Jeon MJ, Kim JY, Chung KA, Park KH. Int Urogynecol J Pelvic Floor Dysfunct. 2002; 13(4):256-60.

11. Jarvis GJ. The place of urodynamic investigation in female urinary incontinence. London: Royal College of Obstetricians and Gynaecologists, 1990.

12. Stewart WF, Van Rooyen JB, Cundiff GW, Abrams P, Herzog AR, Corey R et al. Prevalence and burden of overactive bladder in the United States. World J Urol. 2003;20:327-36.

13. Melville JL, Walker E, Katon W et al. Prevalence of comorbid psychiatric illness and its impact on symptom perception, quality of life, and functional 
status in women with urinary incontinence. Am J Obstet Gynecol. 2002.187:80-7.

14. Shaw C, Tansey R, Jackson C et al. Barriers to help seeking in people with urinary symptoms. Fam Pract. 2001; 18:48-52.

15. Pereira VS, de Melo MV, Correia GN, Dri usso P. Long-term effects of pelvic floor muscle training with vaginal cone in post-menopausal women with urinary incontinence: a randomized controlled trial. Neurourol Urodynam. 2013;32:48-52.

16. Oyen HV and Oyen PV. Urinary Incontinence in Belgium; Prevalence, Correlates and Psychosocial Consequences. Acta Clinica Belgica. 2002;57(4).

17. Kelleher CJ, Cardozo LD, Khullar V. A new questionnaire to assess the quality of life of urinary incontinent women. Br J Obstet Gynaecol, 1997.

18. Kirss F, Lang K, Toompere K, Veerus P. Prevalence and risk factors of urinary incontinence among Estonian postmenopausal women. Spring Plus. 2013;2:524.

19. Milsom I, Abrams P, Cardozo L, Roberts RG, Thuroff J, Wein AJ et al. How widespread are the symptoms of an overactive bladder and how are they managed? A population-based prevalence study. BJU Int. 2001;87(9):760-6.

20. Brown JS, Vittinghoff E, Wyman JF, Stone KL, Nevitt MC, Ensrud KE et al. Urinary incontinence: does it increase risk for falls and fractures? Study of osteoporotic fractures research group. J Am Geriatr Soc. 2000;48(7):721-5.

21. Tsai YC, Liu CH. Urinary incontinence among Taiwanese women: an outpatient study of prevalence, comorbidity, risk factors, and quality of life. Int Urol Nephrol. 2009;41:795-803.
22. Sandvik H, Hunskaar S, Vanvik A, Bratt H, Seim A, Hermstad R. Diagnostic classification of female urinary incontinence: an epidemiological survey corrected for validity. J Clin Epidemiol. 1995;48(3):339-43.

23. Khan S, Ansari MA, Vasenwala SM, Mohsin Z. The hidden burden of urinary incontinence: a community based study. Inte $\mathbf{J}$ Interdisci Multidisci Studies. 2015;2(5):170-176.

24. Pakgohar M, Sabetghadam S, Rahimparvar SFV, Kazemnejad A. Quality of life (QoL) and helpseeking in postmenopausal women with urinary incontinence (UI): a population based study. arch gerontol geriatr. 2014;59:403-7.

25. Saha A, Saha D, Koley AK, Bal R, Dey BC, Chattapadhyay $\mathrm{N}$ et al. Urinary incontinence in postmenopausal women - a study in urban population. J Evol Med Dent Sci. 2013;2(37):7096102.

26. Oberoi SS. Updating income ranges for Kuppuswamy's socio economic status scale for the year 2014. Indian J Public Health. 2015;59:156-7.

27. Mangal A, Kumar V, Panesar S, Talwar R, Raut D, Singh S. Updated BG Prasad socioeconomic classification, 2014: a commentary. Indian J Public Health 2015;59:42-4.

Cite this article as: Khan S, Ansari MA, Vasenwala SM, Mohsin Z. The influence of menopause on urinary incontinence in the women of the community: a cross-sectional study from North India. Int J Reprod Contracept Obstet Gynecol 2017;6:xxx- 